\title{
ANALIZA MOGUĆNOSTI UNAPRJEĐENJA SIGURNOSTI PROMETA KOD MLADIH VOZAČA
}

\author{
Ivana Tomić \\ Studentica, Veleučilište u Rijeci, Vukovarska 58, 51000 Rijeka, Hrvatska; e-mail: itomic@veleri.hr
}

Ivica Barišić

Dr. sc., profesor visoke škole, Veleučilište u Rijeci, Vukovarska 58, 51000 Rijeka, Hrvatska;

e-mail: ivica.barisic@veleri.hr

\section{SAŽETAK}

Prometne nesreće svakodnevna su pojava i u njima stradava velik broj ljudi. Procjene su Svjetske zdravstvene organizacije da će do 2030. godine smrtno stradavanje u prometnim nesrećama postati peti uzrok smrtnosti. Danas su prometne nesreće prvi uzrok stradanja mladih u dobi od 10 do 25 godina. Neiskustvo, prekomjerno samopouzdanje, velika brzina, korištenje opojnih droga i alkohola samo su neki od uzroka koji utječu na prekomjeran broj prometnih nesreća mladih vozača. Sve češće se postavlja pitanje koliko su uopće mladi vozači dobro educirani o sigurnosti u cestovnom prometu te koliko je njihovo znanje u trenutku dobivanja vozačkih dozvola. U radu je dana analiza stanja sigurnosti prometa s naglaskom na mlade vozače te pregled mjera primjenom kojih bi se dugoročno moglo poboljšati stanje sigurnosti mladih vozača na hrvatskim prometnicama.

Ključne riječi: sigurnost cestovnog prometa, mladi vozači, prometna nesreća

\section{UVOD}

Istraživanja pokazuju da kombinacija mladosti i neiskustva dovodi do visokog rizika stradavanja u cestovnom prometu. Mladi ljudi su u prednosti pred starijim ljudima kada je u pitanju stjecanje vještine vožnje; njihove psihofizičke sposobnosti su na visokoj razini i vjerojatno je da će brže od starijih osoba svladati tehniku vožnje, kao i potrebna znanja o prometnim pravilima i propisima. No, problem nastaje kod procjene potencijalno rizičnih situacija u prometu. Mlađi i neiskusni vozači uočavaju manji broj opasnosti u prometu, čine to sporije te podcjenjuju razinu njihove opasnosti. Za razliku od njih, iskusni vozači predviđaju veći broj opasnosti na cesti, brže ih uočavaju, a njihova procjena rizičnosti takvih situacija realnija je i objektivnija nego ona koju čine neiskusni vozači.

Navedeno potkrepljuju brojna istraživanja, među njima i ona Vlade Ujedinjenog Kraljevstva, koja su objavljena 2015. godine pod nazivom „Činjenice o mladim vozačima“. Istraživanja pokazuju da su prometne nesreće i dalje jedan od vodećih uzroka smrtnosti mladih vozača, a većina se prometnih 
nesreća događa zbog neiskustva. Istraživanja ukazuju da mladi vozači imaju veću stopu nezgoda s obzirom na udaljenost koju su prešli u odnosu na sve vozače, a za većinu prometnih nesreća je uzrok prebrza vožnja i gubitak kontrole nad vozilom koji se povezuju s nedostatkom iskustva za procjenu rizičnih situacija u prometu (www.assets.publishing.service.gov.uk).

Loša procjena vlastitih trenutnih psihofizičkih sposobnosti za vožnju sljedeći je problem koji se kod mladih vozača javlja češće nego kod starijih. Postoje određeni čimbenici psihofizičkog stanja koji utječu na sposobnost vožnje: konzumacija alkohola, uzimanje droga, uzimanje psihoaktivnih lijekova, umor, nespavanje, konzumacija hrane, noćna vožnja. Mlade osobe imaju nižu razinu tolerancije organizma na alkohol nego starije osobe, a s obzirom na to da je zadatak vožnje za njih teži i zahtjevniji nego za iskusne vozače, tako su i ometajući efekti uzimanja alkohola na vožnju veći. Utjecaj alkohola na ponašanje kod mladih ljudi veći je i zbog slabije samokontrole ponašanja, što dovodi do raznih emocionalnih stanja koja djeluju nepovoljno na vožnju. Negativne posljedice uzimanja alkohola kod mladih vozača mogu se dodatno kumulirati s posljedicama uzimanja droge, lijekova te efektima umora, nespavanja i noćne vožnje, što zajedno čini i određeni stil života i ponašanja koji je prisutniji kod mladih osoba i, naravno, rizičan za vožnju (http://www.psihoportal. com). Navedeno također potkrepljuje prethodno navedeno istraživanje u Ujedinjenom Kraljevstvu koje ističe da mladi vozači čine četvrtinu vozača poginulih zbog konzumiranja alkohola, $17 \%$ mladih vozača u prometu bilo je nepažljivo, $16 \%$ je izgubilo kontrolu, 22 \% je vozilo neprimjereno uvjetima na cesti i slično (www.assets.publishing.service.gov.uk).

Problem koji se češće javlja kod mladih vozača odnosi se na način komunikacije s ostalim sudionicima u prometu. Vožnja i sudjelovanje u prometu znači komunikaciju s drugim sudionicima u prometu, "dobro voziti" znači paziti na druge osobe u prometu. $U$ prometu je sve više mladih ljudi koji su odrasli u virtualnom svijetu kompjutorskih igrica i internetske komunikacije. Oni nisu u dovoljnoj mjeri razvili toleranciju, obzirnost, izbjegavanje konflikata, kontrolu emocija, ponašanje prilagođeno situaciji i zbog toga mogu imati problem u socijalnoj komunikaciji, što se ne odnosi samo na vožnju. U prometu je potrebna komunikacija s drugim sudionicima, odnosno nema mogućnosti za ispravljanje pogrešaka (http://www.psihoportal.com).

Pored navedenog, upitno je koliko su mladi vozači nakon završetka formalnog dijela obuke i polaganja vozačkog ispita doista spremni za sigurno sudjelovanje u prometnom sustavu i suočavanje sopasnim situacijama u prometu, s kojima se nikad ranije tijekom obuke nisu suočavali. Kako bi se smanjili crni scenariji, potrebno je pravovremeno reagirati i donijeti potrebne mjere za poboljšanje stanja sigurnosti mladih vozača u cestovnom prometu na hrvatskim prometnicama. Stoga je osnovna tema rada ukazati na problem mladih vozača na hrvatskim prometnicama, dok je cilj rada dati prikaz mogućih mjera koje bi utjecale na smanjenje prometnih nesreća te veću sigurnost mladih vozača u cestovnom prometu. 


\section{ANALIZA UTJECAJA MLADIH VOZAČA NA SIGURNOST CESTOVNOG PROMETA}

\section{1 Temeljni čimbenici sigurnosti cestovnog prometa}

Temeljni čimbenici koji utječu na sigurnost cestovnog prometa su: čovjek, vozilo i cesta. Samo njihovo zajedničko sagledavanje, analiziranje i unaprjeđenje može pridonijeti sigurnijem odvijanju prometa. Prema statistikama utjecaj vozača na nastanak prometnih nesreća iznosi 80 do $85 \%$, prometnice 10 do $15 \%$ i vozila oko $5 \%$ (Cerovac, 2001).

Čovjek se u prometu pojavljuje kao izravni sudionik (vozač, pješak, putnik, biciklist), ali i neizravno, u sustavu obrazovanja vozača, u kreiranju pravila i propisa, u nadzoru prometa, u konstruiranju i održavanju vozila, u projektiranju, gradnji i održavanju prometnica, kao organizator prometnog procesa, prometnik ili dispečer u prijevoznom poduzeću i na mnogim drugim mjestima, gdje posredno utječe na sigurnost u prometu. Od iznimne važnosti za sustav sigurnosti cestovnog prometa jest upravo to da osobe koje na takav način mogu utjecati na sigurnost prometa budu svjesne te uloge i svom poslu pristupaju s punom odgovornošću.

Prometna nesreća se prema Zakonu o sigurnosti prometa na cestama definira kao: „događaj na cesti, izazvan kršenjem prometnih propisa, u kojem je sudjelovalo najmanje jedno vozilo u pokretu i u kojem je najmanje jedna osoba ozlijeđena ili poginula, ili u roku 30 dana preminula od posljedica te prometne nesreće, ili je izazvana materijalna šteta." No, klasičnoj definiciji trebalo bi nadodati da je to zapravo i skup čitavog niza nesretnih okolnosti, na koje utječu, pored ljudskog faktora, i stanje vozila, cestovna infrastruktura te prometna okolina i incidentni čimbenici. Prometna nesreća skup je različitih elemenata koji su međusobno povezani te ih se nikako ne može stohastički promatrati. Promatrani sustav potrebno je razdvojiti na čimbenike i posebno ih analizirati kako bismo uvidjeli međusobnu povezanost i određene specifičnosti svakog elementa promatranog sustava (Cerovac, 2001).

\section{2 Utjecaj mladih vozača na sigurnost cestovnog prometa}

Prema Zakonu sigurnosti prometa na cestama mladi vozač u Republici Hrvatskoj je vozač motornog vozila u dobi do navršene 24 . godine života, koji posjeduje vozačku dozvolu izdanu na teritoriju Republike Hrvatske (Zakon o sigurnosti prometa na cestama, NN 67/08, čl. 1a).

Najviše nesreća događa se na početku vozačke karijere, najčešće zbog neiskustva, te na kraju, zbog slabljenja psihofizičkih sposobnosti, odnosno zbog smanjivanja mogućnosti prosudbe i vremena reakcije. S obzirom na mali udio mladih vozača u prometu (8\%), broj nesreća u kojima sudjeluju prilično je velik (11\%). U tim nesrećama je $15 \%$ ukupno stradalih u prometnim nesrećama (https:// www.hak.hr).

U složenim i dinamičnim uvjetima odvijanja cestovnog prometa mladi vozači izloženi su različitim i nepredvidivim događajima i opasnim situacijama s kojim se nisu susretali tijekom osposobljavanja za vozače. 
Problem nerazmjerno velikog sudjelovanja i stradavanja mladih vozača u prometnim nezgodama $\mathrm{u}$ usporedbi s njihovom općom zastupljenošću u cestovnom prometu još uvijek nije riješen. Proveden je velik broj istraživanja o mladim vozačima (posebno u razvijenim zemljama) i nisu još u potpunosti stečena znanja o tome zašto je ta skupina vozača toliko rizična. Proveden je velik broj istraživanja o mladim vozačima (posebno u razvijenim zemljama) i nisu još u potpunosti stečena znanja o tome zašto je ta skupina vozača toliko rizična. Istraživanja Sveučilišta Monash u Australiji navode da smrtnost mladih vozača opada, ali da se prekomjerna zastupljenost mladih vozača u prometnim nesrećama nije promijenila, a kao glavni razlog navode kombinaciju vozačevih godina, iskustva, psihofizičkih osobina vozača te alkohol i slično (https://www.monash.edu). No, istraživanja u Nizozemskoj kao glavni razlog stradavanja mladih vozača navode spol vozača, nedostatak iskustva i godine (http://www.oecd.org). Niti jedno od ovih istraživanja ne može u potpunosti odgovoriti na pitanje zašto je baš ta skupina vozača toliko rizična.

\subsection{Analiza prometnih nesreća u kojima sudjeluju mladi vozači}

Najčešće vrste prometnih nezgoda mladih vozača su: vožnja u slijedu, bočni sudari, čelni sudari, slijetanje s ceste, udar u parkirano vozilo, usporedna vožnja, a najčěsće pogreške koje čine mladi vozači su: neprimjerena i neprilagođena brzina, nepoštovanje prednosti prolaska, vožnja na nedovoljnom razmaku, vožnja unatrag, uključivanje u promet, skretanje i pretjecanje. U odnosu na mjesto događanja prometnih nezgoda najčešce se nezgode događaju na: ravnom dijelu ceste, raskrižjima, u zavojima i na parkirališstima (http://www.sigurno-voziti.net).

$\mathrm{Na}$ temelju podataka iz Biltena o sigurnosti cestovnog prometa, koji svake godine objavljuje Ministarstvo unutarnjih poslova, dobiva se statistička analiza uzroka prometnih nesreća. $\mathrm{Na}$ hrvatskim cestama u posljednjih deset godina dogodile su se 39.294 prometne nesreće u kojima su sudjelovali mladi vozači. U 31,8 posto nesreća stradavale su osobe. Prometne nesreće i nadalje možemo nazvati najvećim ubojicom mladih ljudi u dobi između 10 i 25 godina u cijelom svijetu, pa i u Hrvatskoj. Najčešće vrste prometnih nesreća mladih vozača s poginulim osobama su slijetanje vozilom s ceste, s udjelom smrtnosti od $43 \%$. Slijede sudari vozila u pokretu, s udjelom smrtnosti od $28,7 \%$, te nalet na pješaka s udjelom smrtnosti od $14,8 \%$. Smrtnost u te tri vrste prometnih nesreća predstavlja $86,7 \%$ od ukupnog broja poginulih (Bilten o sigurnosti cestovnog prometa 2017.). 
Tablica 1. Prometne nesreće koje su skrivili mladi vozači

\begin{tabular}{|c|c|c|c|c|c|c|c|c|c|c|c|}
\hline \multicolumn{2}{|c|}{ Vrste prom.nesreca } & 2008. & 2009. & 2010. & 2011. & 2012. & 2013. & 2014. & 2015. & 2016. & 2017. \\
\hline \multirow{6}{*}{$\begin{array}{l}\frac{3}{3} \\
\frac{\pi}{3} \\
\frac{3}{3} \\
\frac{3}{3} \\
\frac{5}{3} \\
\text { क }\end{array}$} & iz suprotnih smjerova & 1.284 & 1.095 & 837 & 737 & 571 & 557 & 408 & 352 & 374 & 394 \\
\hline & bocni smjer & 2.021 & 1.682 & 1.349 & 1.135 & 878 & 827 & 601 & 599 & 634 & 730 \\
\hline & u uspored. voznji & 261 & 190 & 169 & 152 & 115 & 86 & 93 & 63 & 67 & 80 \\
\hline & u voźnji u sljedu & 1.670 & 1.495 & 1.110 & 1.029 & 799 & 611 & 486 & 433 & 513 & 540 \\
\hline & u vožnji unazad & 226 & 216 & 176 & 181 & 153 & 111 & 109 & 91 & 100 & 104 \\
\hline & UKUPNO & 5.462 & 4.678 & 3.641 & 3.23 .4 & 2.516 & 2.192 & 1.697 & 1.538 & 1.688 & 1.848 \\
\hline \multicolumn{2}{|c|}{ Udar voz. u parkirano vozik } & 837 & 779 & 538 & 513 & 422 & 403 & 292 & 290 & 322 & 322 \\
\hline \multicolumn{2}{|c|}{ Sljetanje vozila s ceste } & 2.773 & 459 & 1.725 & 1.681 & 1.216 & 1.101 & 853 & 870 & 872 & 882 \\
\hline \multicolumn{2}{|c|}{ Nalet na bicild } & 90 & 87 & 68 & 100 & 75 & 64 & 29 & 21 & 27 & 30 \\
\hline \multicolumn{2}{|c|}{ Nalet na pjesaka } & 356 & 265 & 221 & 205 & 162 & 129 & 107 & 91 & 97 & 99 \\
\hline Nalet & t na motocikd Ii mop & 79 & 72 & 63 & 57 & 40 & 32 & 27 & 21 & 12 & 2 \\
\hline \multicolumn{2}{|c|}{ Sudar s vlakom } & 4 & 9 & 8 & 4 & 3 & 4 & 2 & 2 & 1 & \\
\hline \multicolumn{2}{|c|}{ Udar voz. u cbjekt na cesti } & 352 & 341 & 141 & 121 & 98 & 67 & 57 & 48 & 47 & 51 \\
\hline \multicolumn{2}{|c|}{ Udar voz. u objekt kraj cest } & $\ldots$ & $\ldots$ & 278 & 250 & 235 & 203 & 157 & 174 & 182 & 214 \\
\hline \multicolumn{2}{|c|}{ Nalet na zivotinjy } & 198 & 85 & 66 & 53 & 52 & 38 & 41 & 20 & 25 & 37 \\
\hline \multicolumn{2}{|c|}{ Ostalo } & 423 & 309 & 208 & 211 & 170 & 170 & 121 & 107 & 108 & 12 \\
\hline \multicolumn{2}{|c|}{ SVEUKUPNO } & 10.574 & 9.084 & 6.957 & 6.429 & 4.989 & 4.403 & 3.383 & 3.182 & 3.381 & 3.63 \\
\hline
\end{tabular}

Izvor: Bilten o sigurnosti cestovnog prometa 2017.

Iz tablice 1 vidljivo je da se ukupan broj prometnih nesreća od 2008. godine do 2016. postupno smanjivao, što je bio cilj Nacionalnog programa sigurnosti cestovnog programa Republike Hrvatske, međutim, u 2017. ukupan broj predmetnih prometnih nesreća u blagom je porastu. Iz tablice je evidentno da je najveći broj prometnih nesreća nastao kao sudar vozila u pokretu. No, u 2017. godini dogodilo se 6.936 manje prometnih nesreća u odnosu na 2008. godinu. lako je to znatan pad, podaci su i dalje zabrinjavajući.

Grafikon 1. Prikaz prometnih nesreća koje su skrivili mladi vozači od 2008. do 2017. godine

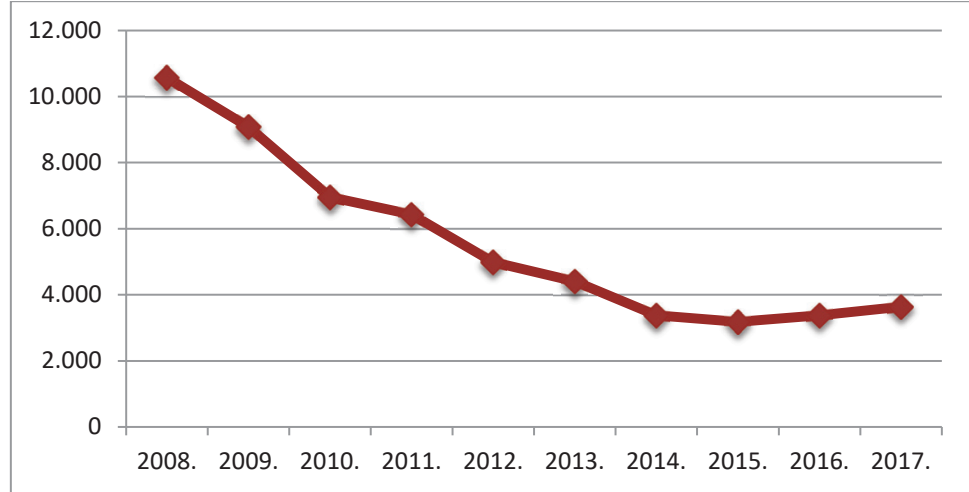

Izvor: obrada autora prema Biltenu o sigurnosti cestovnog prometa 2017.

Prema grafikonu 1 može se vidjeti da se 2009. godine desilo 1.490 nesreća manje u odnosu na 2008., ali i 2.127 nesreća više u odnosu na 2010. godinu. U nastavnom periodu broj nesreća postupno se smanjuje, pa se tako u 2016. godini dogodilo 7.193 manje prometnih nesreća u odnosu na 2008. godinu. No, u 2017. godini bilježi se porast od 7,6 \% u odnosu na prethodnu godinu. 
Tablica 2. Prometne nesreće s nastradalim osobama koje su skrivili mladi vozači

\begin{tabular}{|c|c|c|c|c|c|c|c|c|c|c|c|}
\hline \multicolumn{2}{|c|}{ Vrste prom.nesreca } & 2008. & 2009. & 2010. & 2011. & 2012. & 2013. & 2014. & 2015. & 2016. & 2017. \\
\hline \multirow{5}{*}{$\begin{array}{l}\frac{3}{9} \\
\frac{3}{8} \\
\frac{2}{3} \\
\frac{8}{3} \\
\frac{8}{3}\end{array}$} & iz suprotnih smjerova & 554 & 494 & 381 & 315 & 240 & 262 & 163 & 157 & 171 & 150 \\
\hline & bocni smier & 674 & 544 & 465 & 424 & 322 & 297 & 187 & 206 & 234 & 262 \\
\hline & u uspored. vożnji & 54 & 42 & 32 & 35 & 25 & 17 & 27 & 13 & 23 & 17 \\
\hline & u vożnj unazad & 16 & 14 & 10 & 13 & 10 & 12 & 8 & 4 & 8 & 11 \\
\hline & UKUPNO & 1.854 & 1.589 & 1.250 & 1.117 & 884 & 830 & 591 & 555 & 653 & 654 \\
\hline Udar & voz. u parkirano vozik & 80 & 75 & 40 & 36 & 30 & 20 & 13 & 16 & 12 & 17 \\
\hline \multicolumn{2}{|c|}{ Nalet na bicikd } & 71 & 72 & 56 & 78 & 56 & 53 & 25 & 18 & 21 & 26 \\
\hline \multicolumn{2}{|c|}{ Nalet na pjeșaka } & 350 & 261 & 212 & 203 & 159 & 122 & 106 & 90 & 96 & 92 \\
\hline \multicolumn{2}{|c|}{ Nalet na motocikd Ii moped } & 55 & 51 & 50 & 44 & 23 & 25 & 18 & 16 & 8 & 23 \\
\hline \multicolumn{2}{|c|}{ Sudar s vlakom } & 1 & 5 & 3 & 4 & 1 & 2 & 1 & 1 & 1 & 2 \\
\hline \multicolumn{2}{|c|}{ Udar voz. u objekt na cesti } & 74 & 81 & 28 & 21 & 19 & 12 & 8 & 12 & 6 & 10 \\
\hline \multicolumn{2}{|c|}{ Udar voz. u objekt kraj cest } & $\ldots$ & $\ldots$ & 60 & 78 & 49 & 54 & 41 & 40 & 53 & 51 \\
\hline
\end{tabular}

Izvor: Bilten o sigurnosti cestovnog prometa 2017.

Iz tablice 2 vidljivo je da je najveći broj osoba nastradao prilikom slijetanja vozila s ceste, dok je najmanje osoba nastradalo pri naletu na životinju ili u sudaru s vlakom.

Grafikon 2. Usporedba ukupnog broja prometnih nesreća koje su skrivili mladi vozači po godinama s udjelom nastradalih osoba u njima

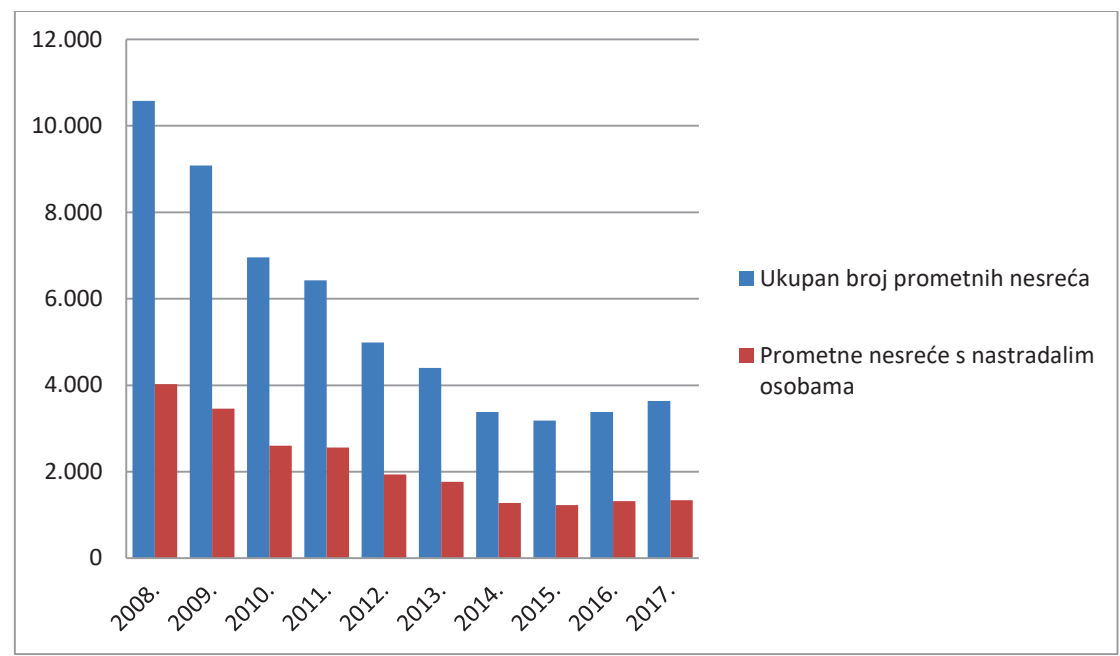

Izvor: obrada autora prema Biltenu o sigurnosti cestovnog prometa 2017.

U grafikonu 2 vidljivo je da se sukladno smanjivanju odnosno povećanju ukupnog broja prometnih nesreća smanjivao odnosno povećavao i broj nastradalih osoba.

Slična situacija događa se kada se gledaju i sve nesreće (grafikon 3). Primjerice, u 2015. godini ukupno se dogodila 32.571 prometna nesreća u kojoj je nastradalo 11.038 osoba, a tijekom 2016. desilo se ukupno 32.757 prometnih nesreća, a udio nastradalih osoba je 32,9 \%. U 2017. godini 
dogodile su se 1.793 nesreće više u odnosu na prethodnu godinu u kojoj su stradale 10.393 osobe (Bilten o sigurnosti cestovnog prometa 2017.)

Grafikon 3. Prometne nesreće i nesreće s nastradalima od 1968. do 2017. godine

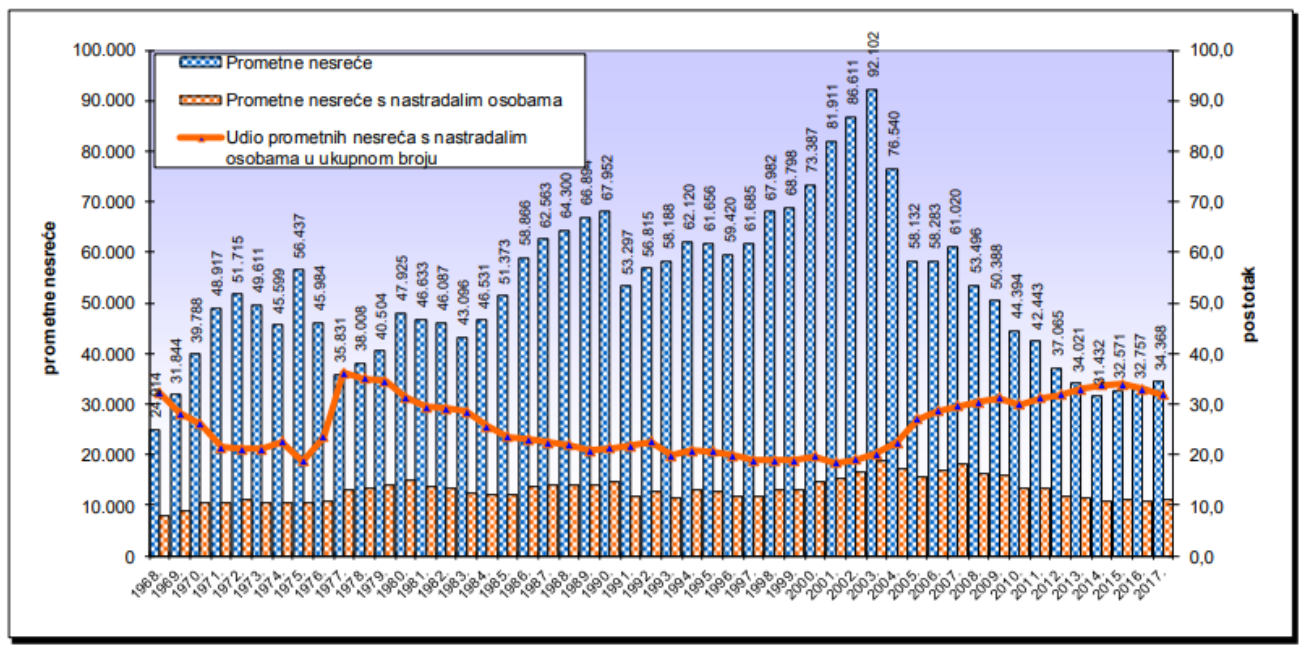

Izvor: Bilten o sigurnosti cestovnog prometa 2017.

\section{MJERE ZA POBOLJŠAVANJE STANJA SIGURNOSTI MLADIH VOZAČA U CESTOVNOM PROMETU}

Za poboljšanje sustava osposobljavanja mladih vozača potrebno je stalno pronalaziti nove i efikasne načine obuke u autoškolama, uvoditi nove i/ili provjerene modele osposobljavanja. Osposobljavanje budućih vozača mora pratiti razvoj suvremenog prometa. Uobičajeni modeli obuke vozača ne mogu dati dobre rezultate u uvjetima sadašnjeg odvijanja cestovnog prometa, kao ni prekasno uvođenje nekog boljeg sustava osposobljavanja. Sigurnost mladih u prometu dobrim dijelom ovisi o prilagođavanju obuke zahtjevima cestovnog prometa. U nastavku su dati prijedlozi mjera kojima bi se moglo utjecati na poboljšanje sigurnosti mladih vozača u cestovnom prometu.

\section{1 Optimalan proces obuke mladih vozača}

Program osposobljavanje kandidata za vozače u autoškolama obuhvaća tri nastavna predmeta:

- $\quad$ Prometni propisi i sigurnosna pravila (PPSP) - 30 nastavnih sati

- Pružanje prve pomoći osobama ozlijeđenim u prometnoj nesreći (PPP) - 9 nastavnih sati

- Upravljanje vozilom (UV) - 35 nastavnih sati. 
Analizom najčesćih uzroka nastanka prometnih nesreća predložen je optimalni proces obuke mladih vozača koji se temelji na postojećem modelu, a uključuje sljedeće izmjene:

- stroža selekcija kandidata za vozača koja bi uključivala zahtjevnije liječničke preglede;

- produžiti vrijeme osposobljavanja na duži vremenski period kako bi tijekom nastavnog predmeta Upravljanje vozilom mogli probati vožnju u više vremenskih uvjeta;

- utvrditi minimalan broj prijeđenih kilometara iz predmeta Upravljanja vozilom prije izlaska na ispit vožnje;

- nakon položenog vozačkog ispita (u periodu od tri godine) uvesti obavezno jednom godišnje prisustvovanje predavanju o uzrocima i posljedicama prometnih nesreća mladih vozača.

\section{2 Primjena simulatora vožnje u procesu obuke vozača}

Simulator vožnje na početku nastajanja bio je zamišljen kao uređaj koji će igranje videoigara učiniti zanimljivijima i realnijima. No, danas simulatori vožnje ne služe samo u svrhe zabave, već se koriste $u$ autoškoli pri obuci kandidata. Koriste se i za istraživanja u medicini te za istraživanja u području ljudskih čimbenika, kako bi se smanjio broj stradalih u prometu. Također se koriste i za istraživanja na sveučilištima te $u$ automobilskoj industriji za dizajn i razvoj novih vozila ili novih naprednih sustava. Njihova tehnologija omogućuje kontinuirano praćenje ponašanja, performansi i pozornosti vozača. Simulator vožnje omogućava interaktivno rekonstruiranje cjelokupnog okruženja (ceste, znakova, vozila i krajolika), a takav virtualni svijet omogućuje kandidatu realan prikaz slobodne vožnje (http://www.fpz.unizg.hr).

$\mathrm{Na}$ simulatoru je moguće simulirati brojne situacije u prometu i vremenske prilike. Kandidati se u virtualnom svijetu susreću sopasnim situacijama u prometu, te na taj način uče kako pravovaljano reagirati bez ikakvih posljedica (npr., bez obzira na godišnje doba tijekom kojeg kandidat polaže vozački ispit, pomoću simulatora može osjetiti kako se vozilo ponaša i na mokroj cesti, u zavoju, na ledu ili snijegu). 


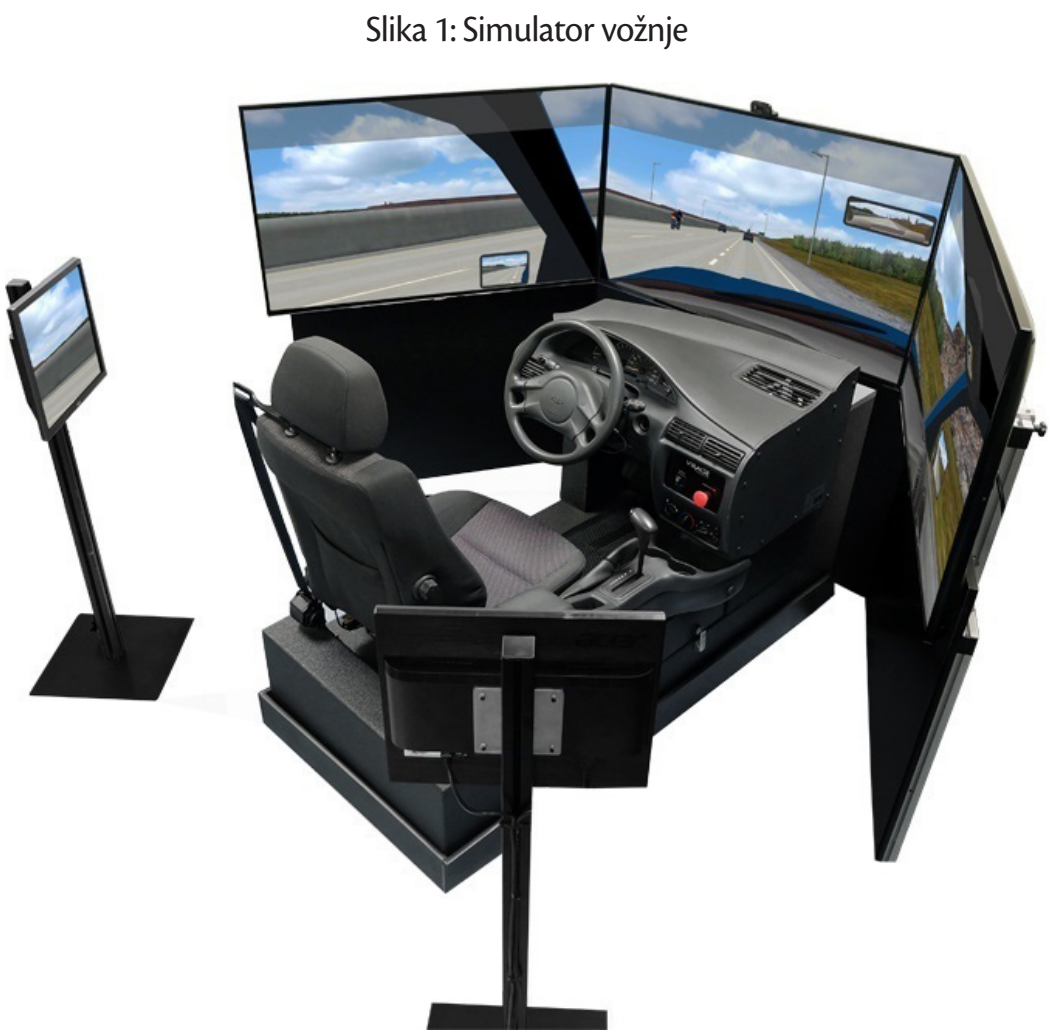

Izvor: www.viragesimulation.com

Simulator vlakova, autobusa, automobila i kamiona samo su neki od tipova koji se mogu koristiti pri obuci kandidata u Njemačkoj, Austriji, Sloveniji, Norveškoj, Francuskoj i drugim europskim zemljama (https://www.fahrsimulatoren.eu). U Republici Hrvatskoj u većini autoškola takva praksa i dalje je nepoznanica. Neke od prednosti simulatora vožnje važne u obuci mladih vozača su:

- realni scenariji događaja u prometu

- zahtjevne situacije koje uključuju upotrebu refleksa

- visok nivo slobode pri pronalaženju rješenja i donošenja odluka

- $\quad$ mogućnosti ponavljanja situacija.

Prema provedenim istraživanjima u Norveškoj i Europi upotrebom simulatora vožnje u obuci vozača postiže se niži nivo rizika u prometu (https://www.sintef.no). Istraživanja također pokazuju da su vozači koji su koristili simulator pri obuci u autoškoli doživjeli upola manje nesreća u odnosu na one koji nisu trenirali na simulatorima. Obuka na simulatorima ima brojne prednosti, svakako može biti vrlo korisna pri polaganju vozačkog ispita, ali i u daljnjem sudjelovanju u prometu, dok se kao jedini nedostatak može izdvojiti iznimno visoka cijena nabave takvog uređaja. (http://www. fpz.unizg.hr). 


\subsection{Uvođenje programa sigurne vožnje}

U zemljama Europske unije programi sigurne vožnje su višegodišnja praksa koja je, statistički gledano, dala iznimno dobre rezultate. Kao dobar primjer može se uzeti Austrija, u kojoj je zakonski od 2003. godine uvedena dodatna edukacija za vozače početnike u više faza. Najvažnija od njih je trening na poligonu za sigurnu vožnju. Nakon uvođenja takve dodatne edukacije broj stradalih u prometu je u stalnom padu. Primjerice, broj poginulih mladih vozača do danas je pao za ukupno $75 \%$, a ukupan broj poginulih u prometu za respektabilnih $50 \%$. U Austriji postoji 10 vježbališta sigurne vožnje, od kojih je posebno poznato vježbalište austrijskog autokluba (ÖAMCT) Teesdorf. Nudi se 12 različitih programa sigurne i napredne vožnje, od kojih su za mlade vozače posebno prilagođeni jednodnevni (intenzivni) i dvodnevni (perfekcionistički) programi osposobljavanja na posebnim prometnim vježbalištima. Treninzi se obavljaju između 3 i 9 mjeseci nakon izdavanja vozačke dozvole B kategorije. Treninzi uključuju i teorijski dio nastave i praktični dio. Kroz program se uči kako upoznati svoje osobne i psihičke granice u vožnji, kako bi se što bolje upoznale i izbjegle opasnosti. U praktičnom dijelu nastave vježba se kako upravljati vozilom u kritičnim situacijama. Uvježbava se kočenje u slučaju opasnosti, naglo kočenje i usporedba puta zaustavljanja, kočenje i skretanje radi izbjegavanja sudara, kočenje na različitim vrstama površine kolnika, posebno na skliskom kolniku, pravilna vožnja u zavoju, kočenje u zavoju te radnje kod proklizavanja u zavoju zadnjeg odnosno prednjeg dijela vozila. Uvježbava se vožnja uz nagib i niz nagib, a polaznik neposredno uočava razlike kočenja s ABS-om i bez njega (https://oeamtc.at).

U Republici Hrvatskoj još je 2004. godine u Zakon o sigurnosti prometa na cestama bila unesena odredba prema kojoj bi svaka osoba koja položi vozački ispit u roku od 6 do 24 mjeseci morala proći i program sigurne vožnje. U suprotnom, novom bi se vozaču oduzela vozačka dozvola. Kriterije i program edukacije i treninga trebalo je sastaviti Ministarstvo unutarnjih poslova, a zakon je trebao stupiti na snagu tri godine kasnije, kada bi se osposobili kadrovi i izradili odgovarajući centri. No, ta odredba nikada nije zaživjela u praksi. Nakon prvotne odgode, u jeku gospodarske krize u 2008. godini ta je odredba u potpunosti uklonjena iz Zakona, na što nije bilo nikakvih reakcija. Nakon toga se u Hrvatskoj o dodatnoj edukaciji i treninzima sigurne vožnje više gotovo nije niti govorilo, što je, nažalost, velika šteta, s obzirom na dobre rezultate koje su te aktivnosti polučile u državama koje su tu obavezu uvele.

Danas u Hrvatskoj postoji nekoliko vježbališta za sigurnu vožnju na kojima se treninzi provode pojedinačno. Ostaje nada da će se kroz neko dogledno vrijeme u Hrvatskoj uvesti sustavna i obvezujuća edukacija za mlade vozače po programu sigurne vožnje.

\subsection{Oznake na vozilima vozača početnika}

Uz oznaku modela vozila ili oznaku s tehničkog pregleda vlasnici na vozila lijepe i mnoge druge oznake. Tako se na stražnjem vjetrobranskom staklu vozila često mogu vidjeti naljepnice s imenima djece koja prikazuju malo dijete. Na taj način vlasnici i roditelji žele drugim vozačima ukazati na to da se u vozilu nalaze mala djeca. Time će drugim sudionicima poslati poruku da budu strpljivi, jer će možda voziti sporije ili parkirati sa strane, te bi time mogli zasmetati drugim sudionicima u prometu. 
Neke zemlje u svijetu odlučile su uvesti oznake, odnosno naljepnice na vozilima koje će označavati pojedine kategorije vozača, u svrhu poboljšanja sigurnosti cestovnog prometa, ali i zaštite svih sudionika prometa. One uvelike pomažu ostalim sudionicima u prometu, koji tako mogu pretpostaviti kakvih je psihofizičkih osobnosti vozač unutar pojedinog vozila, odnosno, pomoći sudionicima u prometu da budu oprezni oko vozila koja nose pojedine simbole te sukladno tome povećaju opreznost pri sudjelovanju u prometu. Naljepnice pomažu i samom vozaču da se riješi straha tijekom vožnje, dajući ostalim vozačima do znanja da je, primjerice, nedavno položio vozački ispit te da mu treba malo više vremena i prostora tijekom vožnje ili da je, možda, vozač starije životne dobi te mu treba više vremena da reagira na pojedine situacije. Pretpostavlja se da, stavljanjem oznake na vozilo, osoba kod ostalih vozača želi izazvati odgovornije, obzirnije i pažljivije postupanje prema pojedinim kategorijama vozača.

Naljepnice za označavanje vozila mladih vozača nisu nikakva nepoznanica niti u našem susjedstvu. Označavanje vozila mladih vozača u Bosni i Hercegovini regulirano je prema Pravilniku o načinu obilježavanja motornog vozila kojim upravlja osoba koja prvi put stekne vozačku dozvolu. Sukladno pravilniku, motorno vozilo kojim u prometu upravlja osoba koja je prvi put stekla vozačku dozvolu u trajanju od dvije godine mora biti označeno posebnim znakom, odnosno tablicom koja ima oblik pravokutnika, bijele je boje i na njoj je crvenom bojom ispisano slovo " $\mathrm{P}$ " latiničnim pismom, ispod koga se upisuje broj vozačke dozvole početnika. Dimenzije tablice za motocikle iznose $14 \mathrm{~cm} \times 10$ $\mathrm{cm}$, dimenzije tablice za ostala motorna vozila iznose $18 \mathrm{~cm}$ x $16 \mathrm{~cm}$. Visina slova "P" na tablici za motocikle iznosi $8 \mathrm{~cm}$, a širina $4 \mathrm{~cm}$. Za neposjedovanje oznake sa slovom "P" propisan je kazna u iznosu od 40 KM (oko 160 kn). Budući da nema ovlaštenih ustanova za izradu ovih naljepnica, dozvoljeno je da ih vozači kupe bilo gdje ili da ih izrade sami, odnosno isprintaju već pripremljene oznake. No, da bi naljepnica bila važeća, obavezno je da ispod slova P bude čitko naznačen broj vozačke dozvole (www.sodalive.ba).

Slika 2. Oznaka za vozače početnike u BiH

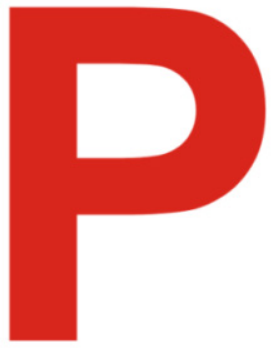

www.vozacka.ba

Izvor: http://www.vozacka.ba

Označavanje vozila regulirano je zakonom i u istočnoj Aziji, odnosno u Japanu. Naime, kada osoba dobije vozaču dozvolu u Japanu, prema zakonu dužna je staviti zeleno-žutu “početničku” naljepnicu 
na prednju i stražnju stranu automobila koji vozi te ju je dužna imati na vozilu godinu dana. Naljepnica vozača početnika upućuju ostale vozače na cesti da bi vozaču početniku možda trebali dati malo više prostora i strpljenja nego običnom vozaču. Ono što je zanimljivo da vozači koji sebe smatraju početnicima mogu i dalje prikazivati znak, čak i nakon razdoblja od godinu dana. Kazne za nestavljanje naljepnica su oko 4.000 jena (oko 240 kn). lako je to relativno mala novčana kazna za Japan, uz novčanu kaznu vozači koji su prekršili zakon dobivaju prekršajne bodove. Zakonom je propisano sankcioniranje vozača koji ne poštuju vozača početnika tako da trube ili na drugi način ometaju u vožnji. Osim naljepnica za vozače početnike, u Japanu je zakonom regulirano postavljanje naljepnica na vozila i za osobe starije životne dobi, invalide, gluhonijeme osobe i sl. (https://www.tofugu.com).

Slika 3. Oblik i pozicija postavljanja naljepnica oznaka za početnike u Japanu

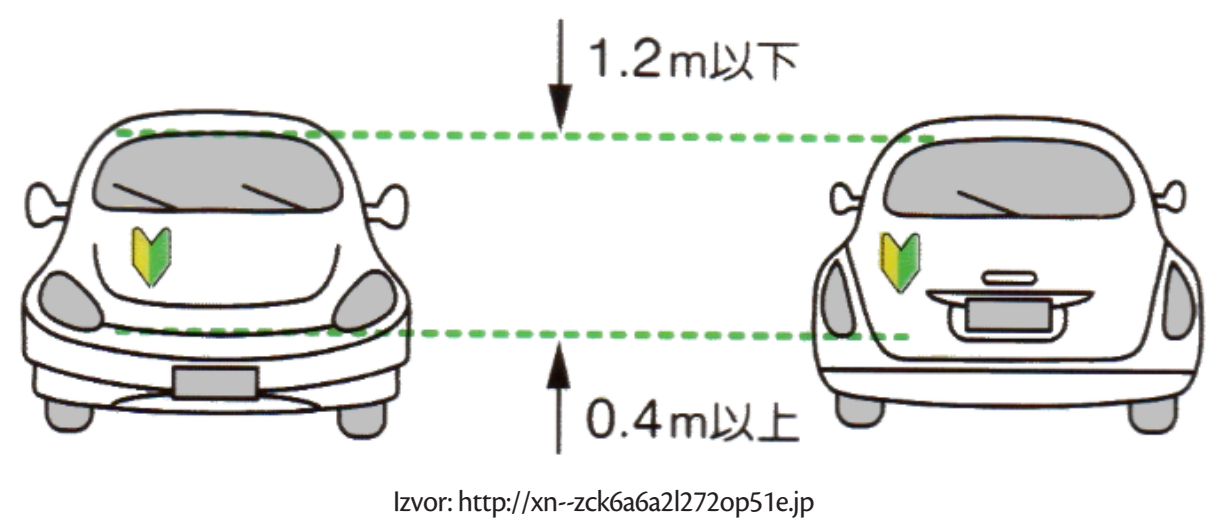

Oznake na vozilu za vozače početnike zakonom su regulirane u Velikoj Britaniji, Italiji, Australiji, SAD-u, isticanjem oznake u obliku velikog slova „L“, dok je u Srbiji zakon još uvijek u izradi.

U Republici Hrvatskoj ne postoji propisan obaveza za postavljanje oznaka za vozače početnike. Mladi vozači mogu samoinicijativno naručiti naljepnice u online trgovinama, na kojoj je napisano veliko slovo „L“ i koje označavaju mladog vozača. Da su i sami vozači početnici svjesni potrebe da ostalim sudionicima u prometu ukažu na svoj status dokazuje niz slika koje se svakodnevno mogu vidjeti na hrvatskim prometnicama, poput raznih natpisa u vlastitoj izradi (npr. „Tek položila! P.S. ne trubi!“, „Pazi tek sam položio“, „Upravio položila“ i sl.). 
Slika 4. Vozači početnici u Hrvatskoj
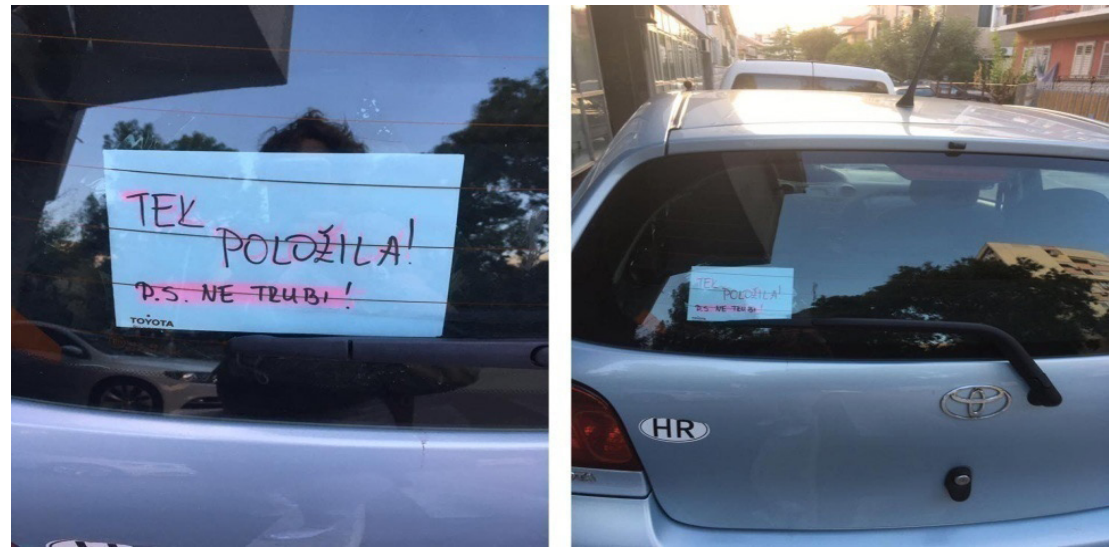

Izvor: www.dalmacijadanas.hr

Iz svega navedenog može se zaključiti da u Republici Hrvatskoj postoji potreba uvođenja u službenu uporabu oznake za označavanje vozila vozača početnika. Na taj se način svim ostalim sudionicima u prometu može pokušati skrenuti pozornost na njihov status.

\section{5 Uvođenje prometnih propisa kao izborni predmet u srednjoškolsko obrazovanje}

Svakodnevni rast cestovnog prometa, ali i sve veća potreba za mobilnošću, dovodi do toga da je potreba za vozačkom dozvolom kod mladih postala nužnost. Potrebno je, međutim, naglasiti da trend nije svagdje takav. Naime, u nekim većim europskim gradovima, poput, primjerice, Beča, u kojima je mobilnost osigurana javnim gradskim prijevozom i biciklima, broj mladih koji posjeduju osobna vozila (pa i vozačku dozvolu) sve je manji. Isto tako treba uzeti u obzir da u ruralnim područjima, gdje je slaba (ili ne postoji) povezanost linijama javnog gradskog prijevoza, mladi stanovnici ovise o vozačkim dozvolama i posjedovanju prijevoznog sredstva. Stoga oni vrlo često tijekom srednjoškolskog obrazovanja ili odmah po njegovom završetku odlaze polagati vozački ispit. Polaganje vozačkog ispita dobar dio mladih shvaća samo kao formalnost.

Jedna od mogućih mjera za poboljšanje stanja sigurnosti mladih vozača u prometu je uvođenje nastavnog predmeta Prometni propisi i sigurnosna pravila u srednje škole kao izbornog predmeta. Ova mjera može se provoditi u sklopu cjelovite reforme obrazovnog sustava u Republici Hrvatskoj. $\mathrm{Na}$ taj bi se način omogućilo mladim vozačima stjecanje trajnih i kvalitetnih znanja iz područja cestovnog prometa, formiranje pozitivnih stavova o prometu, postizanje višeg nivoa prometne kulture te upoznavanje s rizičnim ponašanjima u prometu i opasnostima koje uključuju. Također se, uz predavanja, predlaže puštanje raznih videosnimaka o nastanku prometnih nesreća, stvarnim posljedicama prometnih nesreća, prikazivanje utjecaja alkohola i droga na vožnju, posljedica nekorištenja zaštitnog pojasa i slično. Prijedlog je da se takav način obrazovanja provodi već od prvog razreda srednje škole, pa do kraja školovanja. Još jedna od prednosti bila bi u tome da bi polaznik koji je pohađao navedeni predmet u srednjoj školi prilikom upisa u autoškolu mogao polagati istoimeni ispit u autoškoli s manjim brojem sati ili da je oslobođen slušanja. 


\section{6 Uvođenje prometnog odgoja u školske i predškolske ustanove}

Kao jedna od mjera predlaže se uvođenje prometnog odgoja djece još od predškolske dobi. Prometni odgoj već od najranije dobi ključan je kako bismo dugoročno imali dionike prometa koji će se ponašati odgovorno, sukladno propisima te prepoznavati opasnosti i rizike u prometu. Također, nužan je kako bi prije svega najmlađi stekli društveno prihvatljive osobine, stavove i ponašanja za sudjelovanje u prometu (https://www.sigurnacesta-ppm.hr). Da bi se što uspješnije realizirao sadržaj poučavanja o prometu i stekle navike kulturnog ponašanja u prometu, potrebno je uvesti prometni odgoj u školsko i predškolsko obrazovanje te kroz nastavu i kroz obrazovnu tehnologiju izraditi budućeg svjesnog i odgovornog sudionika u prometu. Nužno je odmalena podučavati djecu o prometnim znakovima, o sigurnom kretanju nogostupom, prelasku preko ceste, korištenju dječjih prijevoznih sredstava te kroz daljnje školovanje upoznavati s važnošću sigurnosti u cestovnom prometu, jer će se jedino kroz takvo obrazovanje izgraditi budući odgovorni i svjesni sudionik u prometu. Pohvalno je što danas u Republici Hrvatskoj imamo više udruga i organizacija koje rade na provođenju edukacije i preventivi i među roditeljima i djecom školske i predškolske dobi.

\section{ZAKLJUČAK}

Mladi vozači zbog pomanjkanja iskustva u prometu te niza okolnosti izloženi su pojačanom riziku stradavanja. Ako se tome pridodaju i problemi koji nastaju pri njihovoj procjeni opasnosti te često njihova neutemeljena uvjerenost $u$ vlastite vozačke sposobnosti, dobivamo potencijalno vrlo opasnu skupinu u smislu mogućeg nastanka prometnih nesreća, što potvrđuju i statistike prometnih nesreća.

Najčešće vrste prometnih nesreća mladih vozača su: vožnja u slijedu, bočni sudari, čelni sudari, slijetanje s ceste, udar u parkirano vozilo, usporedna vožnja, a najčešće pogreške koje čine mladi vozači su: neprimjerena i neprilagođena brzina, nepoštovanje prednosti prolaska, vožnja na nedovoljnom razmaku, vožnja unatrag, uključivanje u promet, skretanje i pretjecanje. No, potrebno je uzeti u obzir i nedovoljnu edukaciju mladih vozača u procesu stjecanja vozačke dozvole.

$\mathrm{Na}$ hrvatskim su se cestama posljednjih deset godina dogodile 39.294 prometne nesreće u kojima su sudjelovali mladi vozači. U 31,8 posto nesreća stradavale su osobe. Prometne su nesreće i nadalje najveći uzrok stradanja mladih ljudi u dobi između 10 i 25 godina u cijelom svijetu, pa i u Hrvatskoj. Najčešće vrste prometnih nesreća mladih vozača s poginulim osobama su slijetanje vozilom s ceste, s udjelom smrtnosti od $43 \%$. Slijede sudari vozila u pokretu s udjelom smrtnosti od $28,7 \%$ te nalet na pješaka s udjelom smrtnosti od $14,8 \%$. Smrtnost u te tri vrste prometnih nesreća predstavlja $86,7 \%$ od ukupnog broja poginulih.

Kako bi se pokušalo smanjiti broj prometnih nesreća, samim time i stradavanje mladih vozača, potrebno je da društvo odmalena oblikuje odgovornog i savjesnog vozača. Stoga se, kako bi se zaštitio mladi vozač u prometu, predlaže uvođenje prometnog odgoja u predškolske ustanove, gdje će se djeca od malih nogu učiti ponašati odgovorno, sukladno propisima te prepoznavati opasnosti i rizike u prometu. Nastavak takvog odgoja predlaže se i u srednjoškolskom obrazovanju, gdje bi se naglasak stavio na učenje prometnih propisa i sigurnosnih pravila, a ono bi zapravo 
pomoglo mladim osobama da lakše savladaju isto gradivo u autoškolama. Osim takvih mjera, predlaže se uvođenje novih tehnologija u autoškole, poput simulatora vožnje, ali i stroži kriteriji pri osposobljavanju vozača. Da se može, ali i da se treba poduzeti nešto u svrhu zaštite mladih vozača, dokazuju iskustva drugih europskih zemalja, kao, primjerice, Austrija, koja godinama provodi proces edukacije kroz škole sigurne vožnje, što je rezultiralo značajnim smanjenjem broja prometnih nesreća i stradanja mladih u prometu.

Naše društvo postaje sve više svjesno problema koji su vezani uz sigurnost cestovnog prometa, posebice kada su u pitanju stradanja mladih. No, mjere koje se poduzimaju još uvijek su daleko ispod sličnih aktivnosti koje se provede u zemljama s najboljim pokazateljima u sigurnosti prometa, tako da na ovom području predstoji još jako puno posla. Ovdje navedene mjere samo su dio širokog spektra mjera i aktivnosti koje bi se trebale poduzimati na razini cjelokupnog društva, kako bi se stanje sigurnosti u prometu općenito, a posebice u ovoj rizičnoj populaciji, dovelo na veću razinu. Trebalo bi provoditi kontinuirano praćenje trenda kretanja stanja sigurnosti kod mladih vozača, analizirati učinkovitost poduzetih mjera te usvajati nove spoznaje do kojih se dolazi na ovom području.

\section{LITERATURA}

Cerovac, V. (2001) Tehnika i sigurnost prometa. Zagreb: Fakultet prometnih znanosti

Ivčević, G., Barišić, l., Golob, M. (2010) „Osposobljavanje mladih vozača u autoškolama u funkciji sigurnosti", Suvremeni promet, 30(5), p. 363-368.

Ministarstvo unutarnjih poslova (2018), Bilten o sigurnosti cestovnog prometa 2017.

Zakon o sigurnosti prometa na cestama, NN 67/08

http://www.psihoportal.com (16. 12. 2018.)

http://www.fpz.unizg.hr (16. 12. 2018.)

http://www.sigurno-voziti.net (16. 12. 2018.)

https://www.hak.hr/ (2. 12. 2018.)

http://www.oryx-asistencija.hr (20. 12. 2018.)

www.sodalive.ba (20. 12. 2018.)

https://www.tofugu.com (20. 11. 2018.)

https://www.oeamtc.at (2. 12. 2018.)

https://www.sigurnacesta-ppm.hr (12. 12. 2018.)

www. www.npscp.hr (16. 12. 2018.)

http://www.oecd.org/itf/37556934.pdf (17. 2. 2019.)

https://www.sintef.no (17. 2. 2019.)

www.assets.publishing.service.gov.uk (17. 2. 2019.) 


\title{
ANALYSIS OF IMPROVING TRAFFIC SAFETY FOR YOUNG DRIVERS
}

\author{
Ivana Tomić \\ Student, Polytechnic of Rijeka, Vukovarska 58, 51000 Rijeka, Croatia; e-mail: itomic@veleri.hr
}

\section{Ivica Barišić}

PhD, College Professor, Polytechnic of Rijeka, Vukovarska 58, 51000 Rijeka, Croatia;

e-mail: ivica.barisic@veleri.hr

\begin{abstract}
Traffic accidents, unfortunately, are an everyday occurrence and they affect a large number of people. The World Health Organization estimates that by 2030 deaths in traffic accidents would become the fifth cause of mortality. Today, traffic accidents are the number one cause of death of 10 to 25 year olds. Inexperience, over-confidence, high speed, use of narcotics and alcohol are just some of the attributes that affect the overwhelming number of traffic accidents of young drivers. The question is whether young drivers are educated about road safety and how much knowledge they possess at the moment of obtaining a driving license. The paper presents an analysis of traffic safety conditions with emphasis on young drivers and an overview of measures to improve the long-term safety of young drivers on Croatian roads.
\end{abstract}

Key words: road traffic safety, young drivers, traffic accidents 